\title{
Woody biochar potential for abandoned mine land restoration in the U.S.: a review
}

\author{
Carlos Rodriguez-Franco $^{1} \mathbb{D} \cdot$ Deborah S. Page-Dumroese $^{2} \mathbb{D}$
}

Received: 19 August 2020 / Accepted: 30 October 2020 / Published online: 14 January 2021

(c) The Author(s) 2021

\begin{abstract}
There are thousands of abandoned mine land (AML) sites in the U.S. that need to be restored to reduce wind and water erosion, provide wildlife forage, shade streams, and improve productivity. Biochar created from woody biomass that would normally be burned in slash piles can be applied to soil to improve soil properties and is one method to restore AML soil productive capacity. Using this 'waste' biomass for biochar and reclamation activities will reduce wildfire risk, air pollution from burning, and particulates released from burning wood. Biochar has the potential to improve water quality, bind heavy metals, or decrease toxic chemical concentrations, while improving soil health to establish sustainable plant cover, thereby preventing soil erosion, leaching, or other unintended, negative environmental consequences. Using forest residues to create biochar also helps reduce woody biomass and improves forest health and resilience. We address concerns surrounding organic and inorganic contaminants on the biochar and how this might affect its' efficacy and provide valuable information to increase restoration activities on AMLs using biochar alone or in combination with other organic amendments. Several examples of AML biochar restoration sites initiated to evaluate short- and long-term above- and belowground ecosystem responses are presented.
\end{abstract}

Keywords Biochar $\cdot$ Abandoned mine lands $\cdot$ Restoration $\cdot$ Woody biomass $\cdot$ Heavy metals

\section{Introduction}

Biochar is gaining attention as a soil amendment for reclamation of waste rock piles and mine tailings on abandoned mine lands (AMLs). Wood-based biochar can ameliorate soil properties such as soil $\mathrm{pH}$ (Page-Dumroese et al. 2017), nitrogen retention (Bai et al. 2015), and phosphorus dynamics (Gao and DeLuca 2018). In addition, wood-based biochar may alter soil bulk density, infiltration, and water holding capacity (Razzaghi et al. 2020). These soil physical and chemical property changes are also likely to improve AML

Carlos Rodriguez-Franco

carlos.rodriguez-franco@usda.gov

Deborah S. Page-Dumroese

debbie.dumroese@usda.gov

1 U.S. Department of Agriculture, Forest Service, Washington Office. Research and Development, 201 14th Street, S.W., 2 NW, Washington, DC 20250, USA

2 U.S. Department of Agriculture, Forest Service, Rocky Mountain Research Station, 1221 S. Main, Moscow, ID 83843, USA soil microbial processes such as carbon (C) mineralization, aggregate stability, and nutrient transformations (Liang et al. 2010). Soil changes associated with biochar applied to AMLs can accelerate reclamation and provide increased ecosystem services to local communities (e.g., water filtration, less erosion).

Wood-based biochar creation is also an opportunity to decrease wildland fire or insect and disease outbreaks on public lands at a time when the United States (U.S.) Department of Agriculture (USDA), Forest Service (hereafter Forest Service) is increasing forest harvest operations. Forest biomass has many uses depending on the size of the material and local, regional, and national markets. However, there is often no end use for limbs, branches, cull sections, and unmerchantable round wood (Anderson et al. 2017) created during harvesting and these materials have traditionally been burned in slash piles because burning is an inexpensive way to dispose of this 'waste' wood (Page-Dumroese et al. 2017). Biochar, made from waste wood, is a way to increase the value of this material while improving forest conditions (e.g., reduced wildfire threat; Bergman et al. 2017), soil health (e.g., less open slash pile burning, improved 
productivity; Razzaghi et al. 2020), and AML restoration by using the abundance of waste material (woody residues) available on national forests across the U.S. These environmental benefits make forest-residue biochar production for AML restoration a very good alternative. Making biochar will take advantage of low cost, low quality woody feedstocks to create a high $\mathrm{C}$ soil amendment that can be used to restore highly disturbed lands that pose an environmental threat to people, water, air, wildlife, and communities.

The Department of Interior Bureau of Land Management (BLM; 2020) maintains an inventory of known AMLs located on public lands, with the majority being abandoned hardrock mines. As of 2017, the inventory for the western U.S. listed over 52,200 sites and 97,600 features from which only $20 \%$ of the sites have either been remediated, have reclamation actions planned or underway, or do not require further action, and the residual $80 \%$ requires additional investigation and/or remediation. Furthermore, the General Accountability office report (Fennell et al. 2020) stated that the Forest Service, the BLM, National Park Service, and the Environmental Protection Agency (EPA) identified about 22,500 hardrock mines that pose or may pose risks to human health or wildlife from long-term exposure to harmful substances. The report indicated that there could be more than 390,000 abandoned hardrock mine features on public lands that were not captured in their database. AML environmental impacts is a serious problem that needs to be addressed to reduce exposure to physical and chemical risks and reduce the chances of accidents, injuries, and legal liabilities.

Mining of gold $(\mathrm{Au})$, lead $(\mathrm{Pb})$, copper $(\mathrm{Cu})$, silver $(\mathrm{Ag})$, and uranium (U) and oil and natural gas extraction were previously encouraged by federal and state governments to develop communities in the western U.S. (BLM 2020). During this time, mine operators could extract the valuable commodities and then abandon the land until 1970. These mining activities caused disturbed landscapes, soil compaction, and contaminated soil and water. Mine spoils can contain residual metals such as cadmium $(\mathrm{Cd})$, chromium $(\mathrm{Cr})$, $\mathrm{Cu}$, and zinc (Zn) or iron or copper sulfides that undergo hydration, oxidation, or acidification reactions causing spoil acidification and resulting in acidic mine drainage that can release heavy metals into the environment. Most AMLs that require restoration are located in the western U.S. Nevertheless, many AMLs are also located in the midwest and eastern U.S. on public lands. In addition, oil and gas drilling sites that have ceased production and have been abandoned are in need of land reclamation to restore agriculture, timber, wildlife, water flow, or C sequestration value (Nallur et al. 2020).

Mine tailings and waste rock areas are often very large and lack vegetative cover because of inhospitable environmental conditions. This is important because populations near abandoned mine sites across the U.S. are increasing. Now, more than 22 million people live within 25 miles of public land, and according to Stein et al. (2007) during the time frame between 2000 and 2030, there will be a considerable increase in housing density, exceeding 21.7 million acres of rural private ownership located within 10 miles of national forests across the conterminous U.S. Therefore, once remote sites are closer to new population centers, AML restoration work becomes more important because of the known hazards and increased human contact with these sites. The large-scale use of woody residues to create biochar for AML restoration activities is a process that works in tandem with forest harvest operations designed to reduce biomass on forested lands to limit wildfire, insect, or disease risks while restoring forest stand structure. Biochar created from non-merchantable residues plays a key role in AML restoration (Ghosh and Maiti 2020) and provides an opportunity to decrease the risk of wildland fire to rural communities, improve rural economies (Sahoo et al. 2019), and provide jobs while developing a strong biochar industry.

We present a review of the literature published from 2010 to March 2020 that assesses the use of woody feedstockproduced biochar to restore AMLs in the U.S. The objective was to synthesize biochar's effects on soil heavy metal availability and plant uptake, health concerns, regulations and standardization, its application in mine lands restoration, and its potential for expanded use across the U.S. with emphasis on the use of wood-derived biochar.

\section{Biochar for soil restoration}

Biochar made from woody feedstocks can alter soil characteristics to facilitate plant growth on mine sites. There has been a large increase in biochar research since 2011 which covers subjects ranging from feedstock, processing, agronomic applications, environmental remediation, life cycle analysis, economic feasibility, markets, and many other uses. From 2010 to 2019 scientific interest in biochar research, in general, has increased as demonstrated by the number of publications (Li et al. 2018): over 16,000 research articles, representing the $87.7 \%$ of the total number of publications with $96.8 \%$ of the articles written in English and published in 2655 journals. As might be expected, these papers highlight various feedstocks, pyrolysis techniques, and applications rates.

Biochar was previously referred to as charcoal and was defined as a pure form of $\mathrm{C}$ because it has no chemical affinity to oxygen, and it does not readily decay in either aerobic or anaerobic conditions. It also is chemically stable and therefore represents a C sink (Seifritz 1993). Lehmann et al. (2006) used the term 'bio-char' and defined it as biomassderived black $\mathrm{C}$, and it is also known as charcoal or woodchar used intentionally for land application. According to the International Biochar Initiative (2015a) and Bridgwater 
(1994), biochar is a solid material obtained from the thermochemical conversion of biomass in an oxygen-limited environment. Manya (2012) in his review of pyrolysis for biochar concluded that slow pyrolysis is the ideal method to produce biochar because of the high charcoal yields. However, for woody feedstocks being used locally on AMLs, biochar can be produced using kilns or other moderate-scale production methods. Woody feedstock biochar can have a range of properties, depending on the wood species (Table 1). Although this type of biochar can be used on agricultural, forest, and range soils for environmental gains such as higher production, water filtration, or water storage (Greco et al. 2019), the ideal properties of biochar used for AMLs would include those listed plus high CEC, low ash content, alkaline $\mathrm{pH}$, and a relatively high surface area. Furthermore, the particle size of wood-based biochar is important for understanding inter- and intra-pore spaces for changes in water holding capacity (Liu et al. 2017).

Wang et al. (2017a, b) noted that biochar made from corn straw and pig manure was used in metal-contaminated soil and for sediment remediation and noted that results can be variable due to the incomplete carbonization of feedstock. This is also true of wood-based biochar (Shaheen et al. 2018). These carbonization differences yield varying proportions of carbonized and amorphous organic matter producing a biochar whose properties may be closer to those of natural soil or sediment organic matter. To best match biochar with a site and local soil conditions, it will be necessary to understand limiting soil factors. For example, soil physicochemical properties can be improved by biochar application because of the following: (1) most biochar is alkaline $(\mathrm{pH}>7)$ and some biochar-amended soils show an increased soil pH (Major et al. 2010), although applications and effects in alkaline soils are more complicated since some alkaline reactions may occur (Gunes et al. 2014); (2) biochar increases soil water holding capacity, particularly on coarse-textured soils because the porous structure contributes to increased water retention within the soil profile ( $\mathrm{Yu}$, Raichle and Sink 2013); and (3) biochar can retain nutrients within the soil profile by limiting leaching or enhancing plant uptake efficiency (Major et al. 2010). Soil improvement after biochar application is dependent on soil texture, density, and porosity (Jeffery et al. 2011). According to the Association of American of Plant Food Control Officials (AAPFCO), to be effective at $\mathrm{C}$ sequestration and improving soil properties, biochar should contain at least $60 \% \mathrm{C}$ (AAPFCO 2016). Wood-based biochar produced at similar temperatures has high $\mathrm{C}$, a high $\mathrm{O}: \mathrm{C}$, and relatively consistent $\mathrm{pH}$ values. Interestingly, biochar made from Arbutus menziesii wood has a low $\mathrm{pH}$ and would likely not be desirable to use on AMLs unless the $\mathrm{pH}$ of the substrate is very alkaline (Table 1).

The importance of having a well-defined biochar product is critical for describing both feedstock and biochar characteristics, chemical composition, and the technology used for production. Having robust standards, guidelines, and regulations for biochar quality also help inform different levels of biochar use. Lately, the focus on the use of biochar for vegetation production and restoration of contaminated soils has called attention to the use of different feedstocks for the biochar production process and the desire to mitigate potential soil toxicity concerns.

\section{Environmental applications for biochar}

Greater levels of interaction between humans and AMLs means that there is greater need for improving degraded soil to revegetate landscapes to reduce erosion and to increase soil organic matter to prevent leaching losses of

Table 1 Select characteristics of a variety of wood-based biochar

\begin{tabular}{|c|c|c|c|c|c|c|c|c|}
\hline Wood species & Process & $\begin{array}{l}\text { Temperature } \\
\left({ }^{\circ} \mathrm{C}\right)\end{array}$ & $\mathrm{pH}$ & $\begin{array}{l}\text { Electrical } \\
\text { conductivity } \\
(\mathrm{dS} / \mathrm{m})\end{array}$ & $\begin{array}{l}\text { Carbon } \\
(\%)\end{array}$ & $\begin{array}{l}\text { Nitrogen } \\
(\mu \mathrm{g} / \mathrm{g})\end{array}$ & $\begin{array}{l}\text { Phosphorus } \\
(\mu \mathrm{g} / \mathrm{g})\end{array}$ & $\mathrm{O}: \mathrm{C}$ \\
\hline Pine bark & Slow pyrolysis & 450 & NA & NA & 75 & NA & NA & 0.25 \\
\hline Mixed conifer sawmill waste & Fast pyrolysis & 450 & 8.1 & 103 & 89 & 0.26 & 490 & 0.11 \\
\hline Quercus garryana & Fast pyrolysis & 450 & 7.9 & 180 & 87 & 0.62 & 880 & 0.17 \\
\hline Thuja plicata & Fast pyrolysis & 450 & 6.5 & 330 & 76 & 0.50 & 960 & 0.20 \\
\hline Cytisus scoparious & Fast pyrolysis & 450 & 7.5 & 235 & 94 & 1.10 & 1300 & 0.22 \\
\hline Arbutus menziesii & Fast pyrolysis & 450 & 4.5 & 789 & 85 & 0.21 & 240 & 0.24 \\
\hline Green mill residue & Two-stage reactor & $700-750$ and $400-550$ & NA & NA & 78 & 0.57 & NA & 0.12 \\
\hline Beetle killed residues & Two-stage reactor & $700-750$ and $400-550$ & NA & NA & 69 & 0.36 & NA & 0.11 \\
\hline
\end{tabular}

After Kim et al. 2015; Page-Dumroese et al. 2017;Domingues et al. 2017

$N A$ indicates data not available 
heavy metals. Biochar has unique properties that can be used for numerous environmental management applications such as pollutant removal, climate change mitigation (C sequestration), soil restoration and increasing plant available water, and energy production, (Gelardi et al. 2019; Lehmann and Joseph 2015; Oliveira et al. 2017; Rasaa et al. 2018; Spokas et al. 2009; Xie et al. 2015). The physiochemical properties of biochar (e.g., pH, electrical conductivity, low bulk density, water holding capacity, long-lived C source) vary among different types of biochar, but these properties make it an attractive amendment for AMLs (Palansooriya et al. 2019). Biochar, in the last 10 years, has been increasingly used in contaminant removal because it is a renewable material, environmentally friendly, and produced at a low cost (Xu et al. 2012). Biochar can be used alone or as a blended product for multiple purposes, such as applications for soil improvement (increase in productivity and decrease in pollution), improving resource use efficiency, land remediation to prevent against particular environmental pollutants, and in greenhouse gas (GHG) mitigation. Biochar also benefits highly weathered or organic matter-deficient soils because it improves soil $\mathrm{pH}$ and can provide nutrients (CraneDroesch et al. 2013). Biochar could replace commercially activated $\mathrm{C}$ used to remove a wide range of organic and inorganic pollutants. However, Gomez-Eyles et al. (2013) concluded that inactivated biochars have limited effectiveness for organic contaminants or $\mathrm{Hg}$, but can be effective for reducing methylmercury $(\mathrm{MeHg}$ ) content. Hardwoodderived biochar has a greater potential to reduce bioavailability of organic and inorganic contaminants than green waste compost in contaminated soil, being particularly effective at decreasing the phytotoxic concentrations of water-soluble $\mathrm{Cd}$ and $\mathrm{Zn}$ and heavier polycyclic aromatic hydrocarbon (PAH) groups (Beesley et al. 2010).

\subsection{Biochar interaction with heavy metals}

Biochar used for reclaiming waste rock and mine tailings on AMLs is complicated because the biochar used must be able to bind heavy metals or reduce toxic substances while also improving soil conditions to increase plant cover to prevent erosion or leaching (Novak et al. 2016a, b). Wood-based biochar, along with biochar from other sources, can bind heavy metals (Nickle (Ni), Cd, $\mathrm{Pb}$, and $\mathrm{Cu}$ ) and reduce their bioavailability (Uchimiya et al. 2011; Penido et al. 2019). Optimizing the microporous structure, active surface functional groups, and other physiochemical properties can facilitate chemical modifications of heavy metals. However, biochar effectiveness to immobilize heavy metals (Xie et al. 2015) from the environment varies greatly among different feedstock types, production methods, and processing conditions (Ahmad et al. 2014; Page-Dumroese, 2018b). Difference in biochar quality and heavy metal bioavailability and plant uptake decreases the accumulation of $\mathrm{Cd}, \mathrm{Pb}, \mathrm{Cu}$, and, $\mathrm{Zn}$ in plant tissues, with variations depending on soil characteristics, type of biochar, plant species, and type of metal contaminants (Chen et al. 2018). These results are consistent for $\mathrm{Zn}$ and $\mathrm{Cd}$ with those from Beesley et al. (2011) who also indicated that several different types of biochars have been found to possess retentive capabilities that can be enhanced by manufacturing biochar with increased cation exchange capacity, surface area, and $\mathrm{pH}$.

The toxic chemicals associated with sewage sludge are another large problem because they contain a significant amount of heavy metals, toxins, and pathogens (Fang et al. 2012), but it can also be used to produce biochar. Woodbased biochar has been particularly effective as a low-cost biosorbent that can remove potentially toxic elements from water (Shaheen et al. 2018). In a risk analysis on the bioavailability and eco-toxicity of heavy metals in biochar obtained from the pyrolysis of pulp and paper mill waste pyrolyzed at different temperatures from $200{ }^{\circ} \mathrm{C}$ to $700{ }^{\circ} \mathrm{C}$, both bioavailability and eco-toxicity were significantly reduced due to biochar characteristics and slow mineralization rates (Devi and Saroha; 2014; Santos et al. 2012). Consequently, pyrolysis of wood-based waste material can be a treatment in pulp and paper mills to create biochar that can be safely applied to soil.

Inorganic elements are not readily degraded in the environment and wood-based biochar can retain complex metal ions on their surfaces, thereby reducing bioavailability (Rinklebe et al. 2016). This points out to the need to produce biochars used on AML sites that have a high surface area and porosity (Shaheen et al. 2018). In addition, biochar produced at $450{ }^{\circ} \mathrm{C}$ with a mix of both hardwood and softwood materials has an antagonistic impact on three plant species metal uptake in soils with two different $\mathrm{pHs}$ while increasing root proliferation (Rees et al. 2016). Fellet et al. (2011) also indicated that prune orchard biochar has potential for mine reclamation because it can help establish a green cover and reduce leaching of $\mathrm{Cd}, \mathrm{Pb}$, thallium ( $\mathrm{Tl}$ ), and $\mathrm{Zn}$ from the tailings. This is of importance in states with large mining operations, suggesting that soil can be restored and used for an agricultural purpose, making it revenue positive. In places where unconventional energy production (hydro-fracturing) has left abandoned well sites, biochar is one way to increase soil restoration and ecosystem services such as improved water quality, wildlife forage, and $\mathrm{C}$ sequestration. The positive effects of using wood-based biochar also include an increase in the ability of soil to immobilize harmful heavy metals which can be toxic to plants (Hayyat et al. 2016).

Several authors have previously pointed out that the presence of toxic compounds and contaminants in several 
types of biochar depends on the nature of the feedstock, pyrolysis conditions, and furnace residence time (Downie et al. 2009). For example, Zielinska and Oleszczuk (2015) note that municipal biosolids can be a valuable source of phosphorus $(\mathrm{P})$, nitrogen $(\mathrm{N})$, microelements, and organic matter all of which have a favorable effect on the properties of soil and the level of crop yields. However, biosolids can contain highly toxic organic compounds such as PAH (see Sect. 3.2). Potentially toxic elements, and pathogenic microorganisms, which may limit their use for soil fertilization or degraded soil reclamation. In general, the advantage of using biochar made from woody residues is that they are low in heavy metals, since forest, invasive woody shrubs, or orchard trees normally grow on soils low in toxic contaminants (Koss et al. 2012). Nonetheless, this could change if trees were harvested from polluted soil and then converted to biochar. For example, trees growing on highly acidic forest soils leached of base cations may show symptoms of declining health because they hyperaccumulate manganese (Mn). This hyperaccumulation is often restricted to leaves and needles because Mn supports photosynthesis (St. Clair and Lynch 2005) and would likely not be present in significant quantities in the biochar since its presence in the bole or bark is minimal.

Rego et al. (2019) indicated that because biochar has a high adsorption capacity, it can prevent leaching of compounds such as nitrates, phosphates, and other ionic solutes into groundwater or streams. Recycling of plant nutrients (e.g., potassium $(\mathrm{K})$, magnesium $(\mathrm{Mg})$, calcium $(\mathrm{Ca})$, sodium ( $\mathrm{Na}$ ), and $\mathrm{P}$ ) to the soil can be achieved using biochar, with concomitant benefits for the soil and crops. The ash composition of the wood-based biochars should also be assessed to check for harmful heavy metals (Rego et al. 2019).

\subsection{Polycyclic aromatic hydrocarbons and other organic pollutants}

Frequently, PAH compounds in soil are a consequence of industrial actions, such as the combustion of wood, coal, and oil (Baird 1995) or smelting processes (Wickstrom and Tolonen 1987). This is similar to the data on biochar that has undergone incomplete combustion of C-containing compounds which can lead to the formation of PAHs (GarciaPerez et al. 2011). However, they note that PAHs and dioxinfurans are not present in high amounts in the biochar and are not considered to be a human health or environmental hazard. Hale et al. (2012) found that total PAH concentrations for slow pyrolysis biochars were dependent on biomass source, pyrolysis temperature, and time. With increasing pyrolysis time and temperature, $\mathrm{PAH}$ concentrations generally decreased. As noted previously, PAHs in biochar are usually below existing environmental quality standards and were also confirmed by Buss et al. (2016). This study of biochar production methods found minimal contamination of PAHs in highly controlled pyrolysis conditions of the highest treatment temperature, residence time, carrier gas flow, and typical feedstocks (wheat/oilseed rape straw pellets, softwood pellets). Sohi et al. (2009), after studying a limited number of biochar samples, also found that PAH concentrations are not at the environmental risk level. However, they also indicated the need for a more systematic evaluation of a complete range of chemical contaminants associated with combustion and of toxic substances within feedstocks. In an analysis of biochar for 16 recognized U.S. EPA PAHs, it was concluded that slow pyrolysis and batch reactors did not influence the PAH concentration in biochar and that pyrolysis of woody biomass yielded biochar with considerably lower PAH contents than straw biomass. These results are consistent with the findings from Fabbri et al. (2013), Keiluweit et al. (2012), Wang et al. (2017a, b), and Zhou et al. (2014). In addition, on contaminated sites, hardwood biochars have been found to reduce soil PAH accumulation by $45 \%$ (Gomez-Eyles et al. 2011), while Pinus radiataderived biochar reduced phenanthrene by $>99 \%$ (Rhodes et al. 2010). Eucalyptus-derived biochar reduced diuron sorption (Yu et al. 2006), chlorpyrifos, and carbofuran (Yu et al. 2009).

Given the long-term stability of wood-based biochar, safe rates of applications need to be determined for individual soil types to avoid possible detrimental effects due to over application (e.g., increased PAHs, reduction in soil productivity). Using biochar for soil remediation has significant benefits, but on AML sites where wildlife forage or crops may be planted, it is critical to limit the PAHs because they are considered mutagenic, carcinogenic, or have toxic properties (Oleszczuk and Kołtowski 2018). Accumulation of PAHs in the food chain must be addressed before soil application. Decreased PAH content on the biochar and in the soil was usually accompanied by a decrease in biochar phytotoxicity and toxicity. Under field conditions, the interaction of soil, root exudates, and biochar can enhance the dissipation of PAHs and enhance microbial diversity (Li et al. 2019).

There is increased global interest in using biochar to enhance soil productivity to meet future global nutrition needs while sustaining environmental quality and it is critical to understand its multifunctional role in agricultural, environmental, and industrial sectors (Novak et al. 2016a, b). Several biochar feedstocks, including pine wood dust, significantly decreased the potential risk of human uptake of phthalates (Wang et al. 2016). Similarly, bamboo biochar enhanced soil sorption of the phthalate compound, but the adsorption capacity was dependent on the soil organic $\mathrm{C}$ levels and the aging characteristics of the biochar (Qin et al. 2016). 
Per- and polyfluorinated compounds (PFCs) are organic pollutants found in fire retardants, surfactants, and other polymers (Key et al. 1997). They are highly persistent, bioaccumulate, and are toxic at high concentrations. Activated $\mathrm{C}$ and two different biochars were examined to determine if they could be used to remediate PFC contaminated soils. Activated $\mathrm{C}$ was capable of almost complete PFC removal during laboratory sorption experiments and was effective at binding PFC in soils. In comparison, biochar made from either mill waste or mixed wood was less effective at binding the PFC compounds (Kupryianchyk et al. 2016). Although untreated wood-based biochar is often ineffective at sorbing organic contaminants, this type of biochar can be steam-activated to increase its effectiveness (Gu et al. 2018). Ahmad et al. (2014) found biochar can be quite similar to activated C. Additionally, wood-based biochar can contain a non-carbonized fraction that may interact with soil contaminants and effectively bind them. These characteristics of biochar show its potential as an effective environmental sorbent for organic and inorganic pollutants. Further, wood-based biochars produced at higher temperatures exhibit higher sorption efficiency for organic contaminant remediation in soil and water and it is associated with the high surface area, microporosity, and electrostatic attractions between charged surfaces in biochar and ionic organic compounds (Xie et al. 2015).

\subsection{Biochar health concerns and handling}

Besides the chemical compounds and potential pollutants in biochar content, there are several environmental considerations that should be addressed when using biochar from any feedstock. For example, Gelardi et al. (2019) noted that dust emissions during production or application may be a concern since biochars have a low bulk density and high porosity (Downie et al. 2009). Blackwell et al. (2009) indicated that biochar dustiness is a negative characteristic because it could be susceptible to losses during transportation and application. These two factors are easily overcome by tarping or otherwise containing a load during transport or mixing the biochar with water or compost during application. Biochar can also be lost through wind and water erosion when applied on top of the soil during farming, so either banding it into the soil or mixing with compost will help reduce dust pollution and water transport. Biochar-caused health risks have not been fully studied, although several authors have pointed out that production method, feedstock type, and handling and storage of biochar must be assessed to inform decisions on human health risks (Blackwell et al. 2009; Gelardi et al. 2019). On forest sites that have an intact forest floor (Oa, Oe, Oi inclusive), the risks of dust and erosion are minimized once the biochar migrates into the organic matter. There are several biochar application methods such as mechanically by spreaders or by hand using animals and farming equipment. This means that there are numerous opportunities and methods to reduce dust emissions, including combining biochar with other on-farm compost material, liquid fertilizer, or lime (Blackwell et al. 2009; Major 2010). However, Sigmund et al. (2019) recommend that during biochar production and application, operators and users should wear protective masks to avoid exposure to small particles and dust.

Another safety concern is during biochar handling. Biochar is a very stable material once it has cooled, but precautions are necessary to prevent spontaneous combustion and avoid a fire hazard during storage. Garcia-Perez et al. (2011) recommend removing dust-sized biochar from the bulk product before storage and placing it in an open dry area for $24 \mathrm{~h}$ before it is stored. Moderate-scale woody biochar can be quenched during the production cycle, thereby reducing the risk of combustion. A method to reduce dust during handling is to pelletize the biochar using green leaves or needles as a binder (Dumroese et al. 2011). This method also increases transportability and ease of application. Finally, Gelardi et al. (2019) indicated that there is a need to better understand what creates dust emissions and which combinations of soil and biochar physical and chemical properties could create hazardous outcomes.

\section{Regulations and standards for labeling and certifications for biochar}

The diversity of feedstocks, production methods, postproduction treatments, and the possible presence of heavy metals or other pollutants point out the need for biochar characterization for different applications (e.g., Avanthi et. al. 2017; Buss et al. 2016; Domene et al. 2015; European Biochar Foundation 2012; International Biochar Initiative (IBI) 2015b; Manya 2012; Oliveira et. al. 2017). For example, designer biochar created for specific soil limitations or contaminants could be used as compared to bulk biochar created from woody biomass at a field site or at bioenergy facilities (Novak et al. 2014). Furthermore, the characterization of biochar properties is critical for marketing various biochar amendments and is essential for optimizing its use for particular applications (e.g., AML restoration, agricultural production). In 2012, the European Biochar Certificate (EBC) issued guidelines for the sustainable production of biochar using a science-based control mechanism to provide consumers with consistent biochar quality and these guidelines also allow producers to show that their product meets clear quality standards. These guidelines are part of the foundational basis for state-of-the-art knowledge transfer for future legislation. The International Biochar Initiative (2015b) developed 
standards for characterization of biochar materials as a soil amendment to achieve uniform product quality and assist the biochar industry by providing information on qualitative and physicochemical properties to consumers. IBI issued these standards as the basis for its Biochar Certification Program. Both IBI and EBC guidelines were compared to determine the differences between the two standards (comparison found at: https://www.europ ean-biochar.org/biochar/media/doc/IBI-EBC.pdf) and to increase collaborative efforts between these two agencies.

In the U.S., biochar producers must follow federal and state air quality regulations for smoke, particulate matter, PAHs, and other pollutants. For example, in 1986 the U.S. Congress passed the Emergency Planning and Community Right-to-Know Act of 1986 (EPCRA) which directs and establishes requirements for all government levels and industry to be followed under the emergency planning and "Community Right to Know" for reporting on hazardous and toxic chemicals. Specifically, Sect. 313 of EPCRA established the Toxics Release Inventory (United States Environmental Protection Agency (EPA), 2020a). This inventory has thresholds for 650 toxic chemicals and provides a tracking system to manage those that pose a human or environmental threat. This relates to biochar manufacturing facilities who would have to report annual amounts on or in biochar products (EPA 2017), but this should not be a problem for woodbased biochar production or products (Oliveira et al. 2017).

Biochar awareness is increasing in the U.S. with biochar producers participating in the voluntary USDA BioPreferred program (Draper 2019). This program is designed to increase the purchase and use of biobased products, incentivize economic development, create new jobs, provide new markets for farm commodities, increase the use of renewable agricultural resources, and contribute to reduced adverse environmental and health impacts (USDA 2020). In addition, the USDA defines biochar as a soil amendment with a minimum threshold of $25 \% \mathrm{C}$, which is much lower than the AAPFCO threshold of 60\% C (AAPFCO 2016). This lower amount of $\mathrm{C}$ allows for a variety of wood-based biochar production methods that range from small kilns to large bioenergy production facilities. Producers are required to have their products tested by qualified, independent laboratories who submit results directly to the USDA for certification. Draper (2019) also pointed out that the Organics Materials Review (OMRI) certifies biochar under their 'ash' or 'wood ash' categories, both of which include crop fertilizer and soil amendments. The OMRI standards also focus on safety and specifically test for heavy metals $(\mathrm{Cd}, \mathrm{Pb}$, and $\mathrm{As})$ based on the USDA Organic Regulations for Organic Compost 7 CFR $\S 205.203$ (c) (OMRI 2020).

\section{Biochar application for abandoned mine land restoration in the U.S.}

With the preceding review on possible benefits and risks of wood-based biochar, what are the opportunities for using biochar to remediate AMLs? Abandoned mine lands are "those lands, waters, and surrounding watersheds contaminated or scarred by extraction, beneficiation or processing of ores and minerals, including phosphate but not coal (EPA 2020b)". Abandoned mine lands also include areas where mining or processing activity is "temporarily inactive." In 2008, the General Accountability Office (GAO; Mittal 2011) developed a standard definition for abandoned hardrock mining sites and used this definition to determine that there are at least 161,000 abandoned hardrock mine sites in the 12 conterminous western states and Alaska, and at least 33,000 sites have degraded the environment by contaminating surface water and groundwater or leaving As and other pollutant-contaminated tailings piles.

Restoration of AMLs is important because mine spoils often contain residual heavy metals (e.g., $\mathrm{Cd}, \mathrm{Cr}, \mathrm{Cu}$, and $\mathrm{Zn}$ ), sulfide bearing minerals (e.g., FeS and $\mathrm{CuS}$ ), or have organic pollutants. These contaminants result in various impacts on the spoils, water, wildlife, and humans. For example, low spoil $\mathrm{pH}$ can reduce or eliminate vegetation cover, further enhancing sediment transport, and off-site heavy metal movement via wind or water erosion and leaching (Novak et al. 2016a, b). Using a wood-based biochar, sourced locally, and applied to AMLs has the potential to immobilize heavy metals, reduce bioavailability, improve water retention capacity and quality, decrease soil erosion, and promote vegetation establishment. In addition, woodbased biochar applied on sites, with or without heavy metals, improves soil conditions for plant establishment further reducing the risk of spoil wind and water erosion (Ippolito et al. 2019; Johnson et al. 2015; Khalid et al. 2016; Sun et al. 2018). Two wood-based biochar feedstocks (pine beetle-killed lodgepole pine and tamarisk) reduced heavy metal bioavailability in mine land soils and increasing biochar application rates resulted in increase in soil $\mathrm{pH}$ (initial, 3.97; final, 7.49 ) and a $55 \%$ to $100 \%$ (i.e., no longer detectable) decrease in metal bioavailability (Ippolito et al. 2017).

\subsection{Wood-based biochar application restoration strategies}

The challenge of AML restoration, given the large number of sites and the extent of mine-impacted landscapes in the U.S., could be addressed by using biochar. We have noted wood-based biochar characteristics that restore soil properties and processes, bind heavy metals, and decrease organic pollutants. These properties are applicable on many polluted 
or disturbed sites and will result in the establishment and growth of plants. Table 2 illustrates several examples of wood-based biochar used alone or in combination with other organic amendments for soil restoration at AMLs. Some study sites are a combination of container and field trials, but all trials are designed to facilitate the establishment of native grass and forb species in the short term. All trials have the long-term goal of establishing a diverse range of woody shrubs and trees. Each AML is a unique combination of soil, spoil, rock, and pollutants, which are not without challenges to restore ecological and hydrologic soil functions (Peltz and Harley 2016). Some other associated challenges are the high costs of traditional reclamation practices, such as site preparation, drainage disposal and treatment, importation of clean topsoil, liming material, and revegetation. The main benefits of using wood-based biochar for AML restoration are the potential lower costs associated with using a locally produced product, recalcitrance in the soil, detoxification, liming, improvements in soil physical, chemical, hydrological, and biological properties, improvement of both water and soil quality, and other benefits such as improvement of wildlife habitat, enhancement of $\mathrm{C}$ retention and sequestration, and associated ecosystems services benefits.

\subsection{Non-contaminated soils}

Many AMLs are not contaminated, but also do not have vegetative growth either because of the loss of soil fines through erosion or because rock was left after stream dredging. On AMLs near a ready supply of woody residues for either conversion to biochar or for wood chips, restoration to build organic matter can result in increased soil cover. Building organic matter on rock piles within AMLs is key to establishing vegetation either by seeding or planting (Page-Dumroese et al. 2018a). In addition, Page-Dumroese (2018b) reported that biochar applications on forest sites should not disturb intact surface organic horizons. In a series of field trials across the western U.S., wood-based biochar generally increased soil moisture, particularly at the $22 \mathrm{Mg} / \mathrm{ha}$ application rate (Page-Dumroese (2018b). Soil moisture content increased from $2 \%$ to $19 \%$, depending on soil type, ecosystem, and pre-application soil organic matter content. The lessons learned were: (1) woody feedstocks offer a source of uniform biochar, but it should be assessed for $\mathrm{pH}$ and other physical and chemical properties; (2) biochar application rates around $22 \mathrm{Mg} /$ ha are the most effective for improving soil physical, chemical, and biological properties; and (3) biochar applied to range and mine sites can be relatively easy with existing equipment (i.e., range rake, tractor), but on forest sites the biochar spreader (PageDumroese et al. 2016) is much more efficient. Often, mine spoils have little to no organic matter within the planting matrix, so biochar additions may have to occur in succession so that the targeted species and ecosystem processes are on the desired trajectory.

\section{Forest management and biochar production}

Low- (or no) value woody residues are used to simultaneously create biochar and promote sustainable forest management in areas at a high risk for wildland fire (Fig. 1). In addition to sustainably reducing tree volume in overstocked forests, biochar has the potential to be used for many applications (e.g., waste management, renewable energy, C sequestration, greenhouse gas emission reduction, crop productivity), but one area that is in immediate need of soil restoration is AMLs. Abandoned mine sites often have extreme growing conditions that limit plant growth and the addition of biochar and other amendments can be effective restoration tools. Furthermore, $\mathrm{C}$ sequestered during biochar application can be $\mathrm{C}$-negative and, therefore, used to actively remove carbon dioxide $\left(\mathrm{CO}_{2}\right)$ from the atmosphere, with potentially major implications for the mitigation of climate change (Lehmann and Joseph 2015).

Page-Dumroese et al. (2017) indicate that the utilization of woody biomass generated from forest restoration treatments has historically been limited by high costs associated with harvesting, processing, and transportation measured against its low value as a fuel for heat and power. Costs to extract material often exceeds its market value, leaving material "stranded", despite increasing interest in utilization. The same is true for biomass generated from salvage logging of dead and dying trees. Logs from these salvage operations have lower value than green logs as a result of damage from the attacking bark beetles, their associated staining fungi, and other associated wood-destroying insects and fungi. Forest operations also tend to be more costly in dead stands, further narrowing profit margins. Consequently, land managers are often forced to pile and burn biomass, leading to environmental damage, air quality degradation, and human health risks. Burning woody biomass in slash piles leads to increased $\mathrm{CO}_{2}$ and particulate emissions, longterm negative soil impacts if piles are large, or $\mathrm{CO}_{2}$ emissions from decaying wood. Converting this 'waste' wood into biochar offers a method for long-term $\mathrm{C}$ sequestration and an opportunity for generating revenue (Fig. 1; Kim et al. 2015; Sahoo et al. 2019; Puettmann et al. 2020). There are many opportunities on federal, state, tribal, and industrial forest lands to use non-merchantable wood for biochar and use it on local AMLs. Currently, non-merchantable woody residue remaining from thinning operations adds to the large volume of biomass found at landings and this material could be efficiently converted into bioenergy, biochar, and other byproducts such as bio-oil. Conventional or fast pyrolysis 


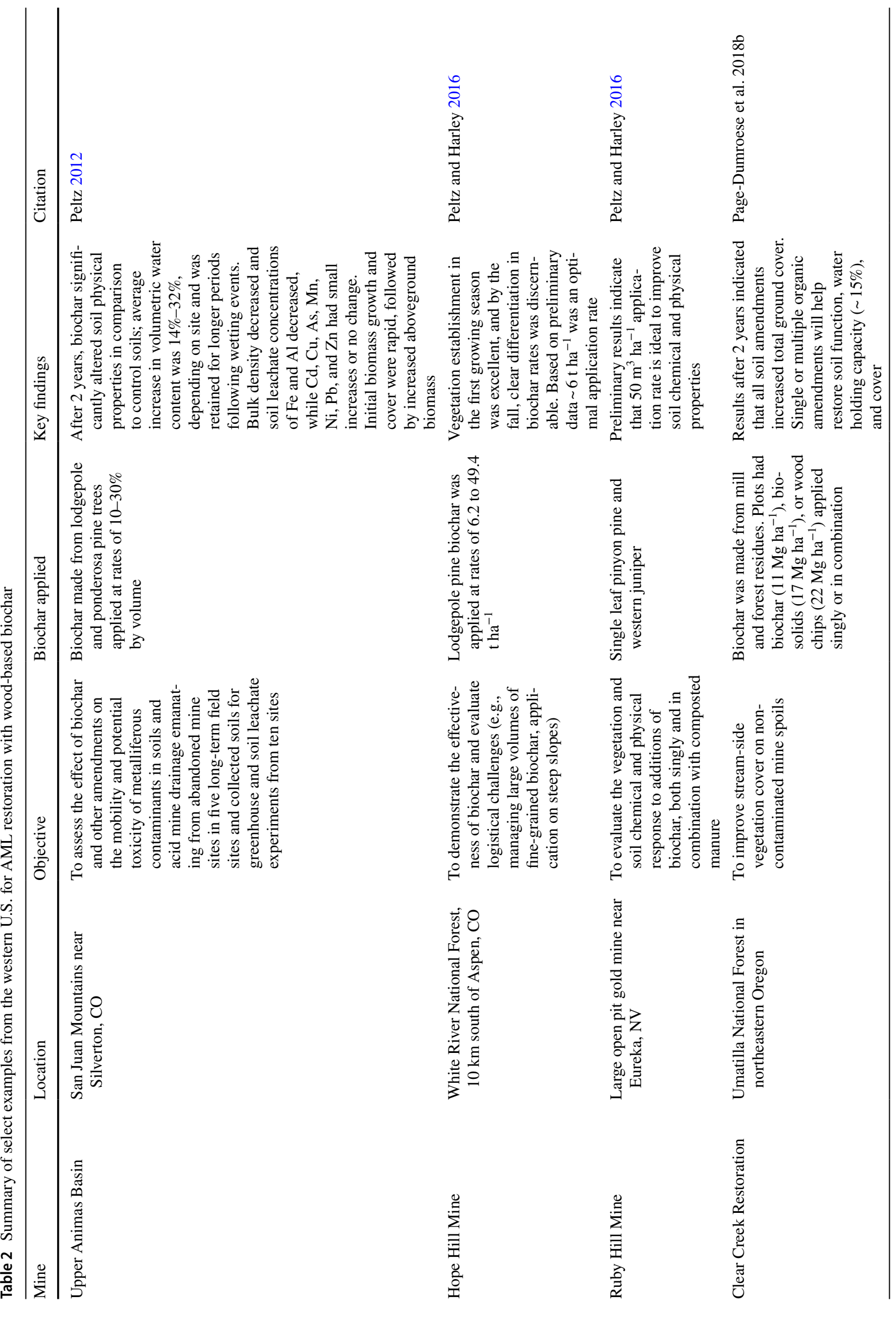




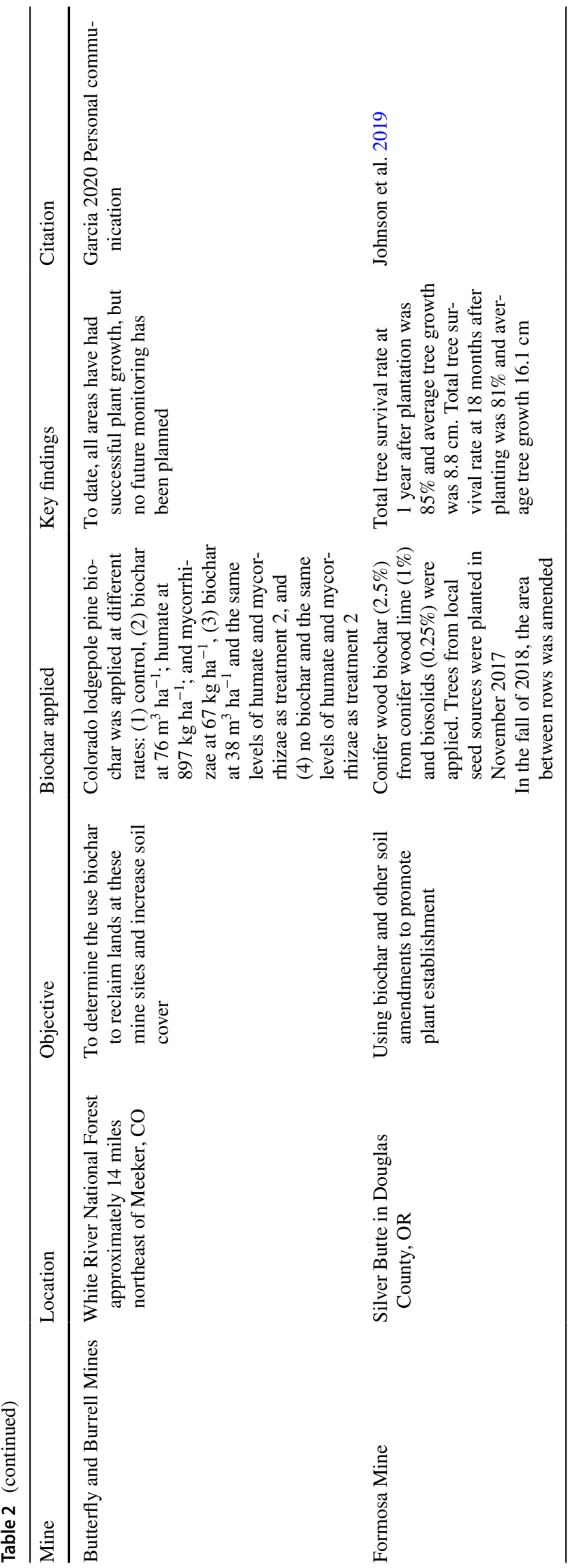

could be the answer, but newer small- (e.g., portable kiln, rick-style slash piles) or moderate-scale (e.g., mobile pyrolysis unit, modified air curtain burner) production systems can be used on-site. This possibility has the advantage of local production for decreased transportation costs to local AML sites (Fig. 1).

Given an increased interest in using woody residues generated from thinning or bioenergy harvests to make biochar and to lower transportation costs of moving non-merchantable woody material to a pyrolysis unit, biochar can be created on site by in-woods deployment of pyrolysis equipment. In-woods or near-woods biochar production has advantages for forest soil or AML restoration (Fig. 1). Current efforts to convert biomass normally burned in slash piles to biochar can result in a $10-35 \%$ by volume increase of recalcitrant C into the soil (Hernandez-Soriano et al. 2016). Droughty conditions, acid mine drainage, heavy metals, or organic pollution can be addressed through the use of biochar on AML sites (Kimetu and Lehmann 2010; Phillips et al. 2016).

The potential for biochar production from federal lands has not been fully explored. However, the One Billion Ton report indicates that there is potential for up to $334 \mathrm{mil}-$ lion dry metric tons of forest wastes and residues that could be produced each year on a sustainable basis in the U.S. (Buford and Neary 2010). Further work must be done to support the vision outlined in the Billion-Ton Update (Langholtz et al. 2016) to use biomass conversion systems that co-produce or produce biochar. Converting this biomass to biochar could be particularly beneficial in the western U.S. where wildfire seasons are longer and generate more severe fires than in previous decades. Wood-based biochar could also increase forest resilience for better adaptation to climate change, increase forest productivity, decrease insect and disease attacks, and other environmental benefits such as $\mathrm{C}$ sequestration or water retention.

To restore AMLs, the use of sorbent amendments and stabilization strategies to reduce contaminates and promote revegetation and environmental recuperation are the current methods. Biochar should be regularly considered as one of the amendments. Biochar has desirable properties to be used as a safe soil amendment and for long-term $\mathrm{C}$ storage, while also improving soil characteristics. One advantage to using biochar as a tool for AML restoration is that it is a more stable form of $\mathrm{C}$ as compared to other remediation techniques. Many soil amendments, such as papermill sludge, biosolids, manures or composts, have the disadvantage of not being highly recalcitrant and lasting within the soil profile for a short time. Biochar has the advantage of having a soil residence time of several hundred to thousands of years.

How much biochar do we need for AML restoration? The amount of biochar and wood chips applied per acre varies according to site conditions, but effective restoration results, starting 2 years after biochar applications, were noted with 


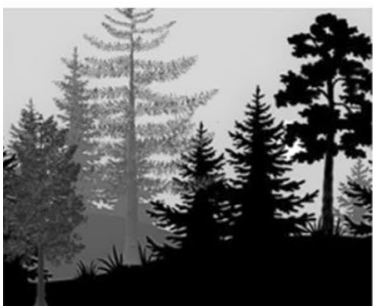

a

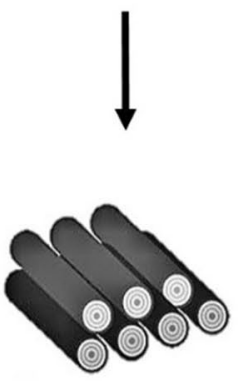

b
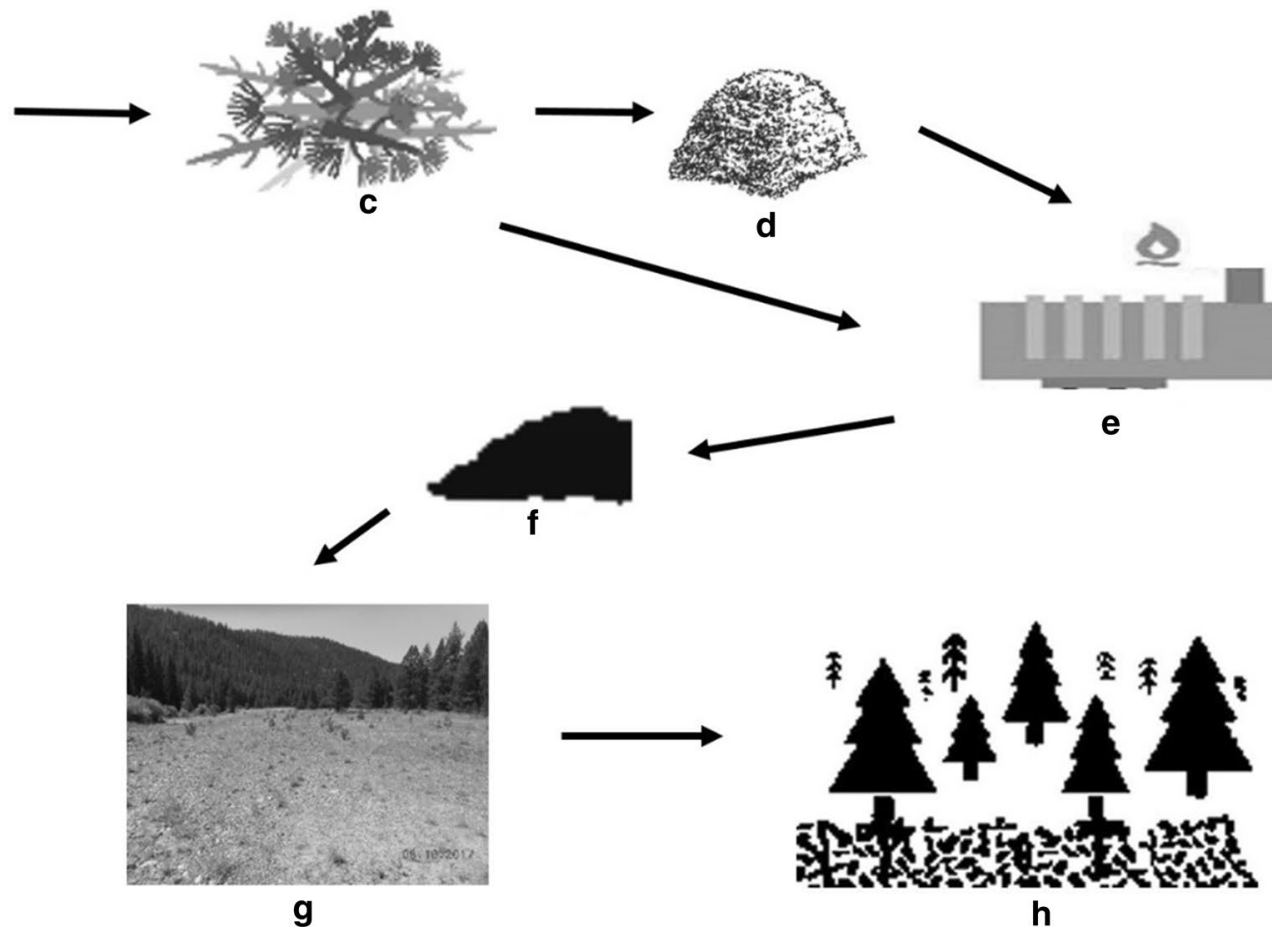

Fig. 1 Biomass supply chain for creation and application of biochar for AML restoration depicting (a) harvesting near abandoned mine sites, (b) use of wood products from sawtimber, (c) using forest resi-

an application rate of $\sim 20 \mathrm{Mg} \mathrm{ha}^{-1}$ (Page-Dumroese et al. 2018a). Several authors have noted wood-based biochar benefits for vegetative cover and improved soil properties (Table 2). In addition, there is an increased retention of bioavailable metals and decreased toxicity, among other environmental benefits. If one goal of AML restoration is to improve soil C from nearly zero in sterile, non-ore-bearing materials, to something closer to normal levels, then the amount of biochar needed could be in excess of $60 \mathrm{Mg} \mathrm{ha}^{-1}$ (Kelly et al. 2014). One additional key benefit of biochar is that it lowers soil bulk density and, therefore, can be effective for ameliorating gas and oil pads or abandoned road compaction.

Although there is considerable knowledge about woodbased biochar use for AML restoration, there are still research needs that should be addressed as this work moves forward. For example, local micro- and macro-fauna should be examined for their tolerance to biochar additions, particle size, and production method. In addition, little is known about invertebrate responses after AML restoration or if biochar just dilutes a contaminated substrate and therefore results are lessened. Future long-term research work that examines ecological, hydrological, and soil-specific responses will contribute to our growing database regarding wood-based biochar. dues directly or for (d) wood chips that are (e) converted to biochar during (f) pyrolysis and (g) biochar added to abandoned mine sites near the forest to $(\mathbf{h})$ restore soil and vegetation

\section{Conclusions, recommendations, and research needs}

Wood-based biochars have been demonstrated to restore AMLs in the U.S. because of the potential environmental benefits at mine sites and the potential to decrease the risk of wildland fires. However, professionals working on AML restoration have previously had concerns about its use because of a lack of knowledge about wood-based biochar and its potential to mitigate heavy metal availability, plant uptake, environmental applications, health concerns, regulations and standardization, and application rates. This literature review was conducted to address those concerns and provide information about the potential of wood-based biochar and additional amendments to be applied to restore AMLs. The main highlights of this review are:

- Wood-based biochar characteristics vary among feedstock species, production methods, and processing conditions.

- Wood-based biochar has low or no PAHs or dioxins/ furans contaminants and, if present, the levels are generally lower than current cleanup levels required by law. Polycyclic aromatic hydrocarbons and dioxins/furans associated with biochar produced under normal opera- 
tion conditions are unlikely to affect human health or pose an environmental hazard.

- Wood-based biochar has a significant potential to address several environmental issues including remediation of pollutants in soil, water, and gaseous media. This could improve soil, water and air quality, C sequestration, and greenhouse gas emissions from the soil. When applied on AMLs it can reduce the bioavailability of heavy metals, improve soil water holding capacity and water quality, decreases soil erosion, and promote vegetation establishment.

- Combining wood-based biochar application with other composts, liquid fertilizer, or lime helps reduce overall costs and minimizes the potential for dust emissions.

- Standards, certification of biochar, and support programs such as the USDA BioPreferred program have been implemented to characterize biochar materials to achieve more consistent levels of product quality. Regulations are in place to ensure that listed toxic chemicals associated with biochar are reported.

- Wood-based biochar results are variable depending on soil properties, biochar type, plant species, and metal contaminants. Wood-based biochar created from woody residues can bind metals, decrease contaminant mobility and bioavailability, stimulate microorganism activity, and promote soil revegetation and recovery.

Acknowledgements Support from the National Agricultural Library Julie Blankenburg, Supervisory Librarian, to conduct the initial search of articles is highly appreciated.

Author contributions CRF: conceptualization, methodology, and writing original draft. DP-D: validation, writing, reviewing, and editing.

Funding The USDA Forest Service supported this work. Funding for biochar analysis was provided by the U.S. Forest Service and by the Biomass Research and Development Initiative, Competitive Grant 2011-10006-30357, from the U.S. Department of Agriculture, National Institute of Food and Agriculture.

\section{Compliance with ethical standards}

Conflict of interest The authors declare that they have no known competing financial interests or personal relationships that could have appeared to influence the work reported in this paper.

Disclaimer The findings and conclusions in this publication are those of the authors and should not be construed to represent any official USDA or U.S. Government determination or policy.

Open Access This article is licensed under a Creative Commons Attribution 4.0 International License, which permits use, sharing, adaptation, distribution and reproduction in any medium or format, as long as you give appropriate credit to the original author(s) and the source, provide a link to the Creative Commons licence, and indicate if changes were made. The images or other third party material in this article are included in the article's Creative Commons licence, unless indicated otherwise in a credit line to the material. If material is not included in the article's Creative Commons licence and your intended use is not permitted by statutory regulation or exceeds the permitted use, you will need to obtain permission directly from the copyright holder. To view a copy of this licence, visit http://creativecommons.org/licenses/by/4.0/.

\section{References}

Association of American of Plant Food Control Officials. (2016) AAPFCO winter-annual 2016. Albuquerque, NM. In Past Meetings 2016. Available via Association of American of Plant Food Control Officials. https://www.aapfco.org/2016. html Accessed 7 May 2020

Ahmad M, Rajapaksha AU, Lim JE, Zhang M, Bolan N, Mohan D, Vithanage M, Lee SS, Ok YS (2014) Biochar as a sorbent for contaminant management in soil and water: a review. Chemosphere 99:19-33. https://doi.org/10.1016/j.chemospher e.2013.10.071

Anderson NM, Bergman RD, Page-Dumroese DS (2017) A supply chain approach to biochar systems [Chapter 2]. In: Bruckman V, Varol E, Apaydin; Uzun, Basak; Liu, Jay, (eds) Biochar: a regional supply chain approach in view of climate change mitigation. Cambridge University Press, Cambridge, pp 25-45

Avanthi DI, Sanchita M, Nabeel KN, Meththika V et al (2017) Advances and future directions of biochar characterization methods and applications. Crit Rev Environ Sci Tech. https:// doi.org/10.1080/10643389.2017.1421844

Bai SH, Reverchon F, Xu CY, Xu Z, Blumfield TJ, Zhao H, Van Zwieten L, Wallace HM (2015) Wood biochar increases nitrogen retention in field settings mainly through abiotic processes. Soil Biol Biochem 90:232-240. https://doi.org/10.1016/j.soilb io. 2015.08 .007

Baird C (1995) Environmental chemistry. W.H. Freeman \& Co., New York

Beesley L, Moreno-Jimenez E, Gomez-Eyles LJ (2010) Effects of biochar and greenwaste compost amendments on mobility, bioavailability and toxicity of inorganic and organic contaminants in a multi-element polluted soil. Environ Pollut. https://doi. org/10.1016/j.envpol.2010.02.003

Beesley L, Moreno-Jimenez E, Gomez-Eyles LJ, Harris E, Robinson B, Sizmur T (2011) A review of biochars' potential role in the remediation, revegetation and restoration of contaminated soils. Environ Pollut. https://doi.org/10.1016/j.envpo 1.2011.07.023

Bergman RD, Gu H, Page-Dumroese DS, Anderson NM (2017) Life cycle analysis of biochar [Chapter 3]. In: Bruckman V, Varol E, Apaydin; Uzun, Basak; Liu, Jay, (eds) Biochar: a regional supply chain approach in view of climate change Mitigation. Cambridge University Press, Cambridge, pp 46-69

Blackwell P, Riethmuller G, Collins M (2009) Biochar application to Soil. In: Lehmann J, Joseph S (eds) Biochar for environmental management: Science and technology. Earthscan, London, pp 207-226

Bridgwater AV (1994) Catalysis in thermal biomass conversion. Gen, Appl Catal A. https://doi.org/10.1016/0926-860X(94)80278-5

Buford MA, Neary DG (2010) Sustainable Biofuels from Forests: Meeting the Challenge, Available via the Ecol Soc Am, Biofuels and Sustainability Reports. https://www.esa.org/biofuelsreports/ files/ESA_Biofuels_Report_Buford_and_Neary_2010.pdf

Buss W, Graham CM, MacKinnon G, Mašek O (2016) Strategies for producing biochars with minimum PAH contamination. J Anal Appl Pyrolysis. https://doi.org/10.1016/j.jaap.2016.04.001 
Chen D, Liu X, Bian R, Cheng K, Zhang X et al (2018) Effects of biochar on availability and plant uptake of heavy metals-a metaanalysis. J Environ Manage. https://doi.org/10.1016/j.jenvm an.2018.05.004

Crane-Droesch A, Abiven S, Jeffery S, Torn MS (2013) Heterogeneous global crop yield responses to biochar: a meta-regression analysis. Environ Res Lett. https://doi.org/10.1088/17489326/8/4/044049

Devi P, Saroha AK (2014) Risk analysis of pyrolyzed biochar made from paper mill effluent treatment plant sludge for bioavailability and eco-toxicity of heavy metals. Bioresour Technol. https://doi. org/10.1016/j.biortech.2014.03.093

Domene X, Enders A, Hanley K, Lehmann J (2015) Ecotoxicological characterization of biochars: role of feedstock and pyrolysis temperature. Sci Total Environ. https://doi.org/10.1016/j.scito tenv.2014.12.035

Domingues RR, Trugilho PF, Silva CA, Melo ICND, Melo LC, Magriotis ZM, Sanchez-Monedero MA (2017) Properties of biochar derived from wood and high-nutrient biomasses with the aim of agronomic and environmental benefits. PloS one, 12(5) https:// doi.org/10.1371/journal.pone.0176884

Downie A, Crosky A, Munroe P (2009) Physical properties of biochar. In: Lehmann J, Joseph S (eds) Biochar for environmental management: science and technology. Earthscan, London, pp 13-32

Draper K (2019). Biochar Labeling and US Certifications. Available via Pyrolist. https://pyrolist.com/blog/biochar-labeling-us-certi fications. Accessed Mar 32020.

Dumroese RK, Heiskanen J, Englund K, Tervahauta A (2011) Pelleted biochar: Chemical and physical properties show potential use as a substrate in container nurseries. Biomass Bioenergy. https:// doi.org/10.1016/j.biombioe.2011.01.053

European Biochar Foundation (2012) European Biochar CertificateGuidelines for a Sustainable Production of Biochar. European Biochar Foundation (EBC), Arbaz, Switzerland. Version 6.2E of 04th February 2016. Available via the European Biochar Certificate. https://www.european-biochar.org/biochar/media/ doc/1454605229759.pdf. Accessed 26 Feb 2020

Fabbri D, Rombolà AG, Torri C, Spokas KA (2013) Determination of polycyclic aromatic hydrocarbons in biochar and biochar amended soil. J Anal Appl Pyrolysis. https://doi.org/10.1016/j. jaap.2012.10.003

Fang L, Yuan N, Wu Y, Zhao X, Sun H (2012) Evolution of heavy metals leachability and speciation in residues of sewage sludge treated by microwave assisted pyrolysis. Appl Mech Mat. https:// doi.org/10.4028/www.scientific.net/AMM.178-181.833

Fellet G, Marchiol L, Delle Vedove G, Peressotti A (2011) Application of biochar on mine tailings: effects and perspectives for land reclamation. Chemosphere. https://doi.org/10.1016/j.chemospher e.2011.03.053

Fennell AM, Erdmann E, Kaas PL, Elmer M et al (2020) Abandoned Hardrock Mines: Information on Number of Mines, Expenditures, and Factors That Limit Efforts to Address Hazards. Report to the Ranking Member, Subcommittee on Interior, Environment, and Related Agencies, Committee on Appropriations, U.S. Senate, GAO-20-238. 51p. United States Government Accountability Office. In Reports and Testimonies. Available via GAO U.S. Government Accountability Office. https://www.gao.gov/produ cts/GAO-20-238 Accessed 11 Mar 2020.

Gao S, DeLuca TH (2018) Wood biochar impacts soil phosphorus dynamics and microbial communities in organically managed-croplands. Soil Biol Biochem 126:144-150. https://doi. org/10.1016/j.soilbio.2018.09.002

Garcia-Perez M, Garcia-Nunez JA, Lewis T, Kruger CE, Kantor S (2011) Methods for producing biochar and advanced bio-fuels in Washington State. Part 3: literature review of technologies for product collection and refining. third project report. department of biological systems engineering and the center for sustaining agriculture and natural resources, Washington State University, Pullman, WA, 129 pp. Available via Pacific Region Bioenergy Partnership. https://pacificbiomass.org/documents/1207034.pdf

Gelardi LD, Li C, Parikh SJ (2019) An emerging environmental concern: Biochar-induced dust emissions and their potentially toxic properties. Sci Total Environ. https://doi.org/10.1016/j.scito tenv.2019.05.007

Ghosh D, Maiti SK (2020) Can biochar reclaim coal mine spoil? J Environ Manag 272:111097. https://doi.org/10.1016/j.jenvm an.2020.111097

Gomez-Eyles JL, Yupanqui C, Beckingham B, Riedel G, Gilmour C, Ghosh U (2013) Evaluation of biochars and activated carbons for in situ remediation of sediments impacted with organics, mercury, And Methylmercury. Env Sci Technol. https://doi. org/10.1021/es403712q

Gomez-Eyles JL, Sizmur T, Collins CD, Hodson ME (2011) Effects of biochar and earthworm Eisenia fetida on the bioavailability of polycyclic aromatic hydrocarbons and potentially toxic elements. Environ Poll 159:616-622. https://doi.org/10.1016/j. envpol.2010.09.037

Greco G, Gonzalez B, Manyà JJ (2019) Operating conditions affecting char yield and its potential stability during slow pyrolysis of biomass: a review. In: Manyà JJ (ed) Advanced carbon materials from biomass: an overview, Zenodo pp 9-19. http://doi. org/10.5281/zenodo.3233733

Gu H, Bergman R, Anderson N, Alanya-Rosenbaum S (2018) Life cycle assessment of activated carbon from woody biomass. Wood Fiber Sci https://doi.org/10.22382/wfs-2018-024

Gunes A, Inal A, Taskin BM, Sahin O, Kaya CE, Atakol A (2014) Effect of phosphorus-enriched biochar and poultry manure on growth and mineral composition of lettuce (Lactuca sativa L. cv.) grown in alkaline soil. Soil Use Manage. https://doi.org/10.1111/ sum. 12114

Hale SE, Lehmann J, Rutherford D, Zimmerman AR et al (2012) Quantifying the total and bioavailable polycyclic aromatic hydrocarbons and dioxins in biochars. Environ Sci Technol. https://doi. org/10.1021/es203984k

Hayyat A, Javed M, Rasheed I, Ali S, Shahid JM, Rizwan M, Javed TM, Ali Q (2016) Role of biochar in remediating heavy metals in soil. In: Ansari AA et al (eds) Phytoremediation. Springer International Publishing, Berlin, pp 421-437

Hernandez-Soriano MC, Kerré B, Kopittke PM, Horemans B, Smolders E (2016) Biochar affects carbon composition and stability in soil: a combined spectroscopy-microscopy study. Sci Rep 6:25127. https://doi.org/10.1038/srep25127

International Biochar Initiative (IBI) (2015a) Standardized product definition and product testing guidelines for biochar that is used in soil. In Biochar Standards. Available via https://biochar-inter national.org/characterizationstandard/ Accessed 26 Feb 2020

International Biochar Initiative (IBI) (2015b) International Biochar Initiative, Standardized Product Definition and Product Testing Guidelines for Biochar that is used in Soil. Final Version. In Biochar Standards. Available via. https://biochar-international. org/characterizationstandard/ Accessed 26 Feb 2020

Ippolito JA, Berry MC, Strawn DG, Novak JM, Levine J, Harley A (2017) Biochars reduce mine land soil bioavailable metals. J Environ Qual. https://doi.org/10.2134/jeq2016.10.0388

Ippolito JA, Cui L, Novak JM, Johnson MG (2019) Biochar for mineland reclamation. In: Ok YS et al (eds) Biochar from biomass and waste. Elsevier, Fundamentals and Applications, pp 75-90

Jeffery S, Verheijen F, Van Der Velde M, Bastos CA (2011) A quantitative review of the effects of biochar application to soils on crop productivity using meta-analysis. Agr Ecosyst Environ. https:// doi.org/10.1016/j.agee.2011.08.015 
Johnson MG, Olszyk D, Power J, Ippolito J et al. (2015) Optimal selection of biochars for remediating metals contaminated mine soils. 5th International Symposium on Soil Organic Matter, Gottingen, Germany, 2015 September 20 - 24. Available via US Environmental Protection Agency. Science Inventory. https://cfpub.epa. gov/si/si_public_record_report.cfm?Lab=NHEERL\&dirEntryId $=309488$ Accessed 6 Jun 2020

Johnson MG, Olszyk D, Bollman M, Storm M et al (2019) A framework for amending mining residuals with biochar and other soil amendments to promote plant establishment. U.S. Biochar Initiative. Biochar and Bioenergy, Conference. June 30 - July 3, 2019. Denver, CO. Available via US Environmental Protection Agency. Science Inventory. https://cfpub.epa.gov/si/si_publi c_record_report.cfm?Lab $=$ NHEERL\&dirEntryId $=345723$ Accessed 10 Dec 2019

Keiluweit M, Kleber M, Sparrow MA, Simoneit BR, Prahl FG (2012) Solvent-extractable polycyclic aromatic hydrocarbons in biochar: influence of pyrolysis temperature and feedstock. Environ Sci Technol. https://pubs.acs.org/doi/10.1021/es302125k

Kelley CN, Peltz CD, Stanton M et al (2014) Biochar application to hardrock mine tailings: soil quality, microbial activity, and toxic element sorption. Appl Geochem 43:35-48. https://doi. org/10.1016/j.apgeochem.2014.02.003

Key DB, Howell DR, Criddle SC (1997) Fluorinated organics in the biosphere. Environ Sci Technol. https://pubs.acs.org/doi/ pdf/10.1021/es961007c

Khalid S, Shahid M, Niazi KN, Murtaza B, Irshad Bibi I, Dumat C (2017) A comparison of technologies for remediation of heavy metal contaminated soils. J Geochem Explor. https:// doi.org/10.1016/j.gexplo.2016.11.021

Kim D, Anderson NM, Chung W (2015) Financial performance of a mobile pyrolysis system used to produced biochar from sawmill residue. For Prod J 65:189-197. https://doi.org/10.13073 /FPJ-D-14-00052

Kimetu JM, Lehmann J (2010) Stability and stabilisation of biochar and green manure in soil with different organic carbon contents. Aust J Soil Res. https://doi.org/10.1071/SR10036

Koss S, Zehetner F, Dellantonio A, Hamid R et al (2012) Characterization of slow pyrolysis biochars: effect of feedstocks and pyrolysis temperature on biochar properties. J Environ Qual. https://doi.org/10.2134/jeq2011.0070

Kupryianchyk D, Hale SE, Breedveld GD, Cornelissen G (2016) Treatment of sites contaminated with perfluorinated compounds using biochar amendment. Chemosphere. https://doi. org/10.1016/j.chemosphere.2015.04.085

Langholtz M, Stokes B, Eaton L (2016) 2016 Billion-Ton Report: Advancing Domestic Resources for a Thriving Bioeconomy, vol. 1. Oak Ridge National Laboratory, Oak Ridge, TN, p. 448p. Economic availability of feedstock. Available via Department of Agriculture, Forest Service Southern Research Station. https://www.srs.fs.usda.gov/pubs/53253

Lehmann J, Joseph S (2015) Biochar for environmental management: an introduction. In: Lehmann J, Joseph S (eds) Biochar for Environmental Management: Science, Technology and Implementation, 2nd ed. Earthscan from Routledge, London, pp. 1-1214. https://www.book2look.com/embed/9781134489602

Lehmann J, Gaunt J, Rondon M (2006) Bio-char sequestration in terrestrial ecosystems-a review. Mitig Adapt Strat Gl. https ://doi.org/10.1007/s11027-005-9006-5

Liang BQ, Lehmann J, Sohi S, Thies JE, O'Neill B, Trujillo L, Gaunt J, Solomon D, Grossman J, Neves EG, Luizao FJ (2010) Black carbon affects the cycling of non-black carbon in soil. Org Geochem 41(2):206-213. https://doi.org/10.1016/j.orgge ochem.2009.09.007

Li X, Song Y, Wang F, Bian Y, Jiang X (2019) Combined effects of maize straw biochar and oxalic acid on the dissipation of polycyclic aromatic hydrocarbons and microbial community structures in soil: a mechanistic study. J Hazard Mater. https:// doi.org/10.1016/j.jhazmat.2018.10.041

Li Y, Jiang S, Wang T, Lin Y, Mao H (2018) Research on biochar via a comprehensive scientometric approach. RSC Adv 8:28700. https://doi.org/10.1039/c8ra05689g

Liu X, Ji R, Shi Y, Wang F, Chen W (2019) Release of polycyclic aromatic hydrocarbons from biochar fine particles in simulated lung fluids: implications for bioavailability and risks of airborne aromatics. Sci Total Environ. https://doi.org/10.1016/j. scitotenv.2018.11.294

Liu Z, Dugan B, Masiello CA, Gonnermann HM (2017) Biochar particle size, shape, and porosity act together to influence soil water properties. Pone. https://doi.org/10.1371/journ al.pone. 0179079

Major J, Rondon M, Molina D, Riha JS, Lehmann J (2010) Maize yield and nutrition during 4 years after biochar application to a Colombian savanna oxisol. Plant Soil. https://doi.org/10.1007/ s11104-010-0327-0

Manyà JJ (2012) Pyrolysis for biochar purposes: a review to establish current knowledge gaps and research needs. Environ Sci Technol. https://doi.org/10.1021/es301029g

Mittal AK (2011) Abandoned mines: information on the number of hardrock mines, cost of cleanup, and value of financial assurances (testimony before the subcommittee on energy and mineral resources, Committee on Natural Resources, House of Representatives No. GAO-11-834T). Available via United States Government Accountability Office. Reports and Testimonies. https://www.gao.gov/products/GAO-11-834T

Mittal AK (2012) Uranium mining: Opportunities exist to improve oversight of financial assurances. A report to the Ranking Member, Committee on Natural Resources, House of Representatives. GAO- 12 -544. 65p. Available via United States Government Accountability Office. Reports and Testimonies. https://www.gao.gov/products/GAO-12-544

Nallur V, McClung MR, Moran MD (2020) Potential for reclamation of abandoned gas wells to restore ecosystem services in the fayetteville shale of arkansas. Environ Manage 66:180-190. https://doi.org/10.1007/s00267-020-01307-3

Novak JM, Cantrell KB, Watts DW, Busscher WJ, Johnson MG (2014) Designing relevant biochars as soil amendments using lignocellulosic-based and manure-based feedstocks. J Soils Sediments. https://doi.org/10.1007/s11368-013-0680-8

Novak JM, Ippolito JA, Lentz RD, Spokas KA et al (2016) Soil health, crop productivity, microbial transport, and mine spoil response to biochars. Bioenerg Res. https://doi.org/10.1007/ s12155-016-9720-8

Novak J, Ro K, Ok YS, Sigua G et al (2016) Biochars multifunctional role as a novel technology in the agricultural, environmental, and industrial sectors. Chemosphere. https://doi.org/10.1016/j. chemosphere.2015.06.066

Oleszczuk P, Kołtowski M (2018) Changes of total and freely dissolved polycyclic aromatic hydrocarbons and toxicity of biochars treated with various aging processes. Environ Pollut. https://doi.org/10.1016/j.envpol.2018.01.073

Oliveira RF, Patela KA, Jaisib PD, Sushil Adhikaric S, Lud H, Khanal KS (2017) Environmental application of biochar: Current status and perspectives. Bioresour Technol. https://doi. org/10.1016/j.biortech.2017.08.122

Organic Materials Review Institute. (2020) Available via Organic Materials Review Institute, Compost Standards. https://www. omri.org/compost-standards. Accessed 6 Aug 2020

Page-Dumroese DS, Anderson NM, Windell KN, Englund K, Jump K (2016) Development and use of a commercial-scale biochar spreader. Gen. Tech. Rep. RMRS-GTR-354. Fort Collins, CO: U.S. Accessible via Department of Agriculture, Forest Service, 
Rocky Mountain Research Station. 10 p. https://www.fs.usda. gov/treesearch/pubs/52309 Accessed 13 Feb 2020

Page-Dumroese DS, Busse MD, Archuleta JG, McAvoy D, Roussel E (2017) Methods to reduce forest residue volume after timber harvesting and produce black carbon. Scientifica 2745764:8p. https://doi.org/10.1155/2017/2745764

Page-Dumroese DS, Ott MR, Strawn DG, Tirocke JM (2018a) Using organic amendments to restore soil physical and chemical properties of a mine site in Northeastern Oregon, USA. Appl Eng Agr. https://doi.org/10.13031/aea.12399

Page-Dumroese D (2018b) Evaluating impacts in forest soils. In: Waste to Wisdom. Utilizing forest residues for the production of bioenergy and biobased products. Final Report. 78p. In Waste to Wisdom: Utilizing Forest Residues for the Production of Bioenergy and Biobased Products. Available via Project Final Report. https://wastetowisdom.com/reports/

Palansooriya KM, Ok YS, Awad YM et al (2019) Impacts of biochar application on upland agriculture: a review. J Environ Manag 234:52-64. https://doi.org/10.1016/j.jenvman.2018.12.085

Peltz CD (2012) Biochar Data Summary (2011) Mountain Studies Institute and Research Services LLC in cooperation with the Bureau of Land Management and the U.S Forest Service. Research Services LLC. Available via Research Services LLC. https://www.researchservicesco.com/2012_Biochar_Data_ Summary.pdf. Accessed 5 Mar 2020

Peltz CD, Harley A (2016) Biochar application for abandoned mine land reclamation. In: Guo M, He Z, Uchimiya SM (eds) Agricultural and Environmental Applications of Biochar: Advances and Barriers. Soil Sci Soc Am Special Publications. 63. Wisconsin. pp 325-340. https://acsess.onlinelibrary.wiley.com/doi/ book/10.2136/sssaspecpub63

Penido ES, Martins GC, Matos Mendes TB, Melo LCA et al (2019) Combining biochar and sewage sludge for immobilization of heavy metals in mining soils. Safety 172:326-333. https://doi. org/10.1016/j.ecoenv.2019.01.110

Phillips CL, Trippe KM, Wittaker G et al (2016) Gasified grass and wood biochars facilitate plant establishment in acid mine spoils. Heavy Metal J Environ Qual 45:1013-1020. https://doi. org/10.2134/jeq2015.09.0470

Puettmann M, Sahoo K, Wilson K, Oneil E (2020) Life cycle assessment of biochar produced from forest residues using portable systems. J Clean Environ 250:119564. https://doi.org/10.1016/j. jclepro.2019.119564

Qin P, Wang H, Yang X, He L et al (2018) Bamboo-and pig-derived biochars reduce leaching losses of dibutyl phthalate, cadmium, and lead from co-contaminated soils. Chemosphere. https://doi. org/10.1016/j.chemosphere.2018.01.162

Rasaa K, Heikkinena J, Hannulab M, Arstilac K, Kuljua K, Hyväluomaa J (2018) How and why does willow biochar increase a clay soil water retention capacity? Biomass Bioenergy. https:// doi.org/10.1016/j.biombioe.2018.10.004

Razzaghi F, Obour PB, Arthur E (2020) Does biochar improve soil water retention? A systematic review and meta-analysis Geoderma 361:114055. https://doi.org/10.1016/j.geode rma.2019.114055

Rego F, Wang J, Yang Y, Bridgewater VA (2019) Pyrolysis of biomass and wastes in a continuous screw reactor for char production. In: Manyà J (ed) Advanced carbon materials from biomass: an overview, pp 21-31. http://doi.org/10.5281/zenodo.3233733

Rees F, Sterckeman T, Morel JL (2016) Root development of nonaccumulating and hyperaccumulating plants in metal-contaminated soils amended with biochar. Chemosphere. https://doi. org/10.1016/j.chemosphere.2015.03.068

Rhodes AH, McAllister LC, Chen R, Semple KT (2010) Impact of activated charcoal on the mineralization of 14C-phenanthrene in soils. Chemosphere 79:463-469. https://doi.org/10.1016/j.chemo sphere.2010.01.032

Rinklebe J, Shaheen SM, Frohne T (2016) Amendment of biochar reduces the release of toxic elements under dynamic redox conditions in a contaminated floodplain soil. Chemosphere. https:// doi.org/10.1016/j.chemosphere.2015.03.067

Shaheen SM, Niazi NK, Hassan EEN, Bibi I, Wang H, Tsang DWC, Ok SY, Bolan N, Rinklebe J (2019) Wood-based biochar for the removal of potentially toxic elements in water and wastewater: a critical review. Int Mater Rev 64(4):216-247. https://doi. org/10.1080/09506608.2018.1473096

Sahoo K, Bilek E, Bergman R, Mani S (2019) Techno-economic analysis of producing solid biofuels and biochar from forest residues using portable systems. Appl Energy 235:578-590. https://doi. org/10.1016/j.apenergy.2018.10.076

Santos F, Torn SM, Bird JA (2012) Biological degradation of pyrogenic organic matter in temperate forest soils. Soil Biol Biochem. https ://doi.org/10.1016/j.soilbio.2012.04.005

Seifritz W (1993) Should we store carbon in charcoal? Int J Hydrogen Energ. https://doi.org/10.1016/0360-3199(93)90219-Z

Sohi S, Loez-Capel E, Krull E, Bol R (2009) Biochar, climate change and soil: A review to guide future research. CSIRO Land and Water Science Report 05/09, 64 pp. Available via CSIRO Research Publications Repository. https://doi. org/10.4225/08/58597219a199a

Sigmund G, Huber D, Bucheli TD, Baumann M, Borth N, Guebitz GM, Hofmann T (2017) Cytotoxicity of biochar: a workplace safety concern? Environ Sci Technol https://doi.org/10.1021/acs. estlett.7b00267

Spokas KA, Koskinen WC, Baker JM, Reicosky DC (2009) Impacts of woodchip biochar additions on greenhouse gas production and sorption/degradation of two herbicides in a Minnesota soil. Chemosphere. https://doi.org/10.1016/j.chemosphere.2009.06.053

Stein SM, Alig RJ, White EM, Comas SJ et al (2007) National forests on the edge: Development pressures on America's national forests and grasslands. Gen. Tech. Rep. PNW-GTR- 728. Portland, OR: U.S. Department of Agriculture, Forest Service, Pacific Northwest Research Station. 26 p. In. Open Space Conservation. Available via Forests on the Edge. https://www.fs.fed.us/ openspace/fote/GTR728.pdf Accessed 5 Mar 2020

St Clair SB, Lynch LP (2005) Element accumulation patterns of deciduous and evergreen tree seedlings on acid soils: implications for sensitivity to manganese toxicity. Tree Physiol. https:// doi.org/10.1093/treephys/25.1.85

Sun W, Zhang S, Su C (2018) Impact of biochar on the bioremediation and phytoremediation of heavy metal(loid)s in soil. In: Shiomi N (ed) Adv Bioremediat and Phytoremediat. Pp 149-168. http:// dx.doi.org/10.5772/intechopen.70349

Uchimiya M, Chang S, Klasson KT (2011) Screening biochars for heavy metal retention in soil: role of oxygen functional groups. J Hazard Mater. https://doi.org/10.1016/j.biortech.2013.06.033

United States Department of Agriculture (2020) In BioPreferred. Available via US Department of Agriculture. https://www.biopr eferred.gov/BioPreferred/faces/pages/AboutBioPreferred.xhtml . Accessed 6 Aug 2020

United States Environmental Protection Agency. (2001) Emergency Planning and Community Right-to-Know Section 313. Available via US Environmental Protection Agency. Office of Public Information. https://ofmpub.epa.gov/apex/guideme_ext/guideme/ file/pesticides\%20and\%20persistant\%20bioaccumulative\%20tox ic\%20(pbt)\%20chemicals.pdf. Accessed 10 Jul 2020.

United States Environmental Protection Agency (2008) Polycyclic Aromatic Hydrocarbons (PAHs). Available via US Environmental Protection Agency. Office of Solid Waste. https://archive.epa. gov/epawaste/hazard/wastemin/web/pdf/pahs.pdf. Accessed 27 Feb 2020 
United States Environmental Protection Agency (2017) The Emergency Planning and Community Right-to-Know Act. Available via US Environmental Protection Agency. Office of Land and Emergency Management. https://www.epa.gov/sites/production /files/2017-08/documents/epcra_fact_sheet_overview_8-2-17.pdf Accessed 10 Jul 2020

United States Environmental Protection Agency (2020a). Toxic release inventory chemicals by groupings. Available via US Environmental Protection Agency. TRI National Analysis 2018. https://edg.epa.gov/metadata/catalog/search/resource/detai 1s.page?uuid=\%7BAEFC2511-C887-4C63-8DA8-58E154CC4E 14\%7D. Accessed 29 Jul 2020

United States Environmental Protection Agency (2020b). Abandoned Mine Lands. Available via US Environmental Protection Agency. Superfund. https://www.epa.gov/superfund/abandoned-minelands-basic-information-0 Accessed 29 Jul 2020.

United States Department of Interior, Bureau of Land Management (2020) Abandoned Mine Lands. Available via BLM. https:// www.blm.gov/programs/public-safety-and-fire/abandoned-minelands Accessed 5 March 2020

United States Department of Interior Bureau of Land Management (2020) AML Inventory. Available via Bureau of Land Management. Abandoned Mine Lands. https://www.blm.gov/programs/ public-safety-and-fire/abandoned-mine-lands/blm-aml-inventory. Accessed 31 Mar 2020

Wang C, Wang Y, Herath H (2017) Polycyclic aromatic hydrocarbons (PAHs) in biochar-their formation, occurrence and analysis: a review. Org Geochem. https://doi.org/10.1016/j.orggeochem .2017.09.001

Wang M, Zhu Y, Cheng L, Andserson B, Zhao X, Wang D, Ding A (2017) Review on utilization of biochar for metal-contaminated soil and sediment remediation. J Environ Sci. https://doi. org/10.1016/j.jes.2017.08.004

Wang Z, Han L, Sun K, Jin J et al (2016) Sorption of four hydrophobic organic contaminants by biochars derived from maize straw, wood dust and swine manure at different pyrolytic temperatures. Chemosphere. https://doi.org/10.1016/j.chemospher e.2015.08.042

Wickstrom K, Tolonen K (1987) The history of airborne polycyclic aromatic hydrocarbons (PAH) on perylene as recorded in dated lake sediments. Water Air Soil Pollut. https://doi.org/10.1007/ BF00227691

Xie T, Reddy RK, Wang C, Yargicoglu E, Spokas K (2015) Characteristics and applications of biochar for environmental remediation: a review. Crit Rev Environ Sci Techn. https://doi. org/10.1080/10643389.2014.924180

Xu T, Lou L, Cao R, Duan D, Chen Y, (2012) Effect of bamboo biochar on pentachlorophenol leachability and bioavailability in agricultural soil. Sci Total Environ https://doi.org/10.1016/j. scitotenv.2011.11.005

Yu O-K, Raichle B, Sink S (2013) Impact of biochar on the water holding capacity of loamy sand soil. Int J Energ Environ Eng. https:// doi.org/10.1186/2251-6832-4-44

Yu XY, Ying GG, Kookana RS (2006) Sorption and desorption behaviors of diuron in soils amended with charcoal. J Agric and Food Chem 54:8545-8550. https://doi.org/10.1021/jf061354y

Yu XY, Ying GG, Kookana RS (2009) reduced plant uptake of pesticides with biochar additions to soil. Chemosphere 76:655-671. https://doi.org/10.1016/j.chemosphere.2009.04.001

Zhou H, Wu C, Onwudili JA, Meng A, Zhang Y, Williams PT (2014) Polycyclic aromatic hydrocarbon formation from the pyrolysis/ gasification of lignin at different reaction conditions. Energ Fuels. https://pubs.acs.org/doi/10.1021/ef5013769

Zielinska A, Oleszczuk P (2015) The conversion of sewage sludge into biochar reduces polycyclic aromatic hydrocarbon content and ecotoxicity but increases trace metal content. Biomass Bioenergy. https://doi.org/10.1016/j.biombioe.2015.02.019 